\title{
Physiology and Function of the Tight Junction
}

\author{
James M. Anderson ${ }^{1}$ and Christina M. Van Itallie ${ }^{2}$ \\ ${ }^{1}$ Department of Cell and Molecular Physiology, University of North Carolina at Chapel Hill, \\ 6312 MBRB, Chapel Hill, North Carolina 27599-7545 \\ ${ }^{2}$ Department of Medicine, Division of Gastroenterology and Hepatology, University of North Carolina at \\ Chapel Hill, Chapel Hill, North Carolina 27599-7545 \\ Correspondence: jandersn@med.unc.edu
}

\begin{abstract}
Understanding of tight junctions has evolved from their historical perception as inert solute barriers to recognition of their physiological and biochemical complexity. Many proteins are specifically localized to tight junctions, including cytoplasmic actin-binding proteins and adhesive transmembrane proteins. Among the latter are claudins, which are critical barrier proteins. Current information suggests that the paracellular barrier is most usefully modeled as having two physiologic components: a system of charge-selective small pores, $4 \AA$ in radius, and a second pathway created by larger discontinuities in the barrier, lacking charge or size discrimination. The first pathway is influenced by claudin expression patterns and the second is likely controlled by different proteins and signals. Recent information on claudin function and disease-causing mutations have led to a more complete understanding of their role in barrier formation, but progress is impeded by lack of high resolution structural information.
\end{abstract}

Tising ight junctions form the continuous intercellular barrier between epithelial cells, which is required to separate tissue spaces and regulate selective movement of solutes across the epithelium. Although there are now $>40$ proteins (Schneeberger and Lynch 2004; Yamazaki et al. 2008) identified within the tight junction, the claudin family of transmembrane proteins, named from the Latin claudere to close, has emerged as the most critical for defining tight junction selectivity. Here, we review evidence that claudins regulate permselectivity (including size, electrical resistance, and ionic charge preference) derived from studies in cultured epithelial cell models and the phenotypes of knockout mice and human mutants. We highlight the physiologic relevance of selectivity but only briefly discuss how it might be physiologically regulated and altered in pathologic situations. We develop the perspective that the barrier is usefully described as having two pathways: first a system of charge-selective claudin-based pores that are $4 \AA$ in radius and a second pathway created by larger discontinuities in the barrier and that lacks charge and size discrimination. The two pathways may be controlled by different proteins and signals. This article focuses on claudins and physiology and is meant to be read as a companion to the article in this collection contributed by

Editors: W. James Nelson and Elaine Fuchs

Additional Perspectives on Cell Junctions available at www.cshperspectives.org

Copyright (C) 2009 Cold Spring Harbor Laboratory Press; all rights reserved; doi: 10.1101/cshperspect.a002584

Cite this article as Cold Spring Harb Perspect Biol 2009;1:a002584 
M. Furuse, which focuses on the molecular structure, proteins, and cell biology of the tight junction (Furuse 2009). The reader is also referred to comprehensive reviews on physiology (Diamond 1978; Powell 1981; Van Itallie and Anderson 2006), pathophysiology (Turner 2006; Schmitz et al. 1999; Nusrat et al. 2001), regulation (Tsukita et al. 2008; Gonzalez-Mariscal et al. 2008), and molecular components of the junction (Schneeberger and Lynch 2004; Krause et al. 2008; GonzalezMariscal et al. 2003).

\section{EVOLUTION OF IDEAS ABOUT PARACELLULAR TRANSPORT AND THE RELEVANCE OF TIGHT JUNCTION PERMSELECTIVITY}

Explicit description of a sealing contact between epithelial cells can first be found in the biologic literature in the latter part of the 19th century (Cereijido and Anderson 2001). Staining of epithelial tissues, such as the intestine, with vital dyes revealed a distinct region at the apical end of the lateral cell interspaces referred to as the "terminal bar." This was thought to be an absolute barrier preventing anything from passing between cells. By the early 20th century, studies began to acknowledge that some material, for example macrophages and water, could cross epithelia through the paracellular space.

Our current understanding of how material selectively crosses epithelia originates with the pioneering work of Hans Ussing and associates, beginning in the 1940s. Ussing addressed the question of how sodium ions are moved in a directional fashion across the epithelium of frog skin, resulting in a steady-state electrical potential across the epithelium (KoefeldJohnsen and Ussing 1958; Ussing and Zerahn 1951). Their first conceptual breakthrough, the so-called "two membrane model," stated that the apical and basal membrane surfaces had different conductance properties, namely, that sodium enters the cell across the apical membrane down its concentration gradient (later shown to be through $\mathrm{Na}$ channels) but was transported in an energy-dependent fashion out the basal lateral surface (later shown to be by the NaK-ATPase). Ironically, they chose to study an epithelium with one of the electrically tightest junctions in nature, leading them initially to discount the possibility of ion movements between cells. Subsequent inconsistencies between their model and the data led to the realization that $\mathrm{Cl}^{-}$ions must be following $\mathrm{Na}^{+}$in a passive fashion through the tight junction (based on electrical circuit modeling, they called this the shunt pathway) coupled to the electrical gradient generated by active $\mathrm{Na}^{+}$transport (Ussing and Windhager 1964). This was the beginning of understanding about how transcellular and paracellular transport are physiologically coupled (Fig. 1).

In the 1960s, investigators began to study transport across other epithelia, such as the gallbladder, where the paracellular resistance was much lower than in frog skin (reviewed in Diamond 1977). Because the transepithelial electrical resistance (TER) was so much lower than frog skin, there was initial concern that these tissues were damaged during experimental preparation and this explained their low resistance. Gradually, it was accepted that intact normal epithelia display a wide range of electrical resistances (Table 1). Because the cell membranes are generally of very high resistance

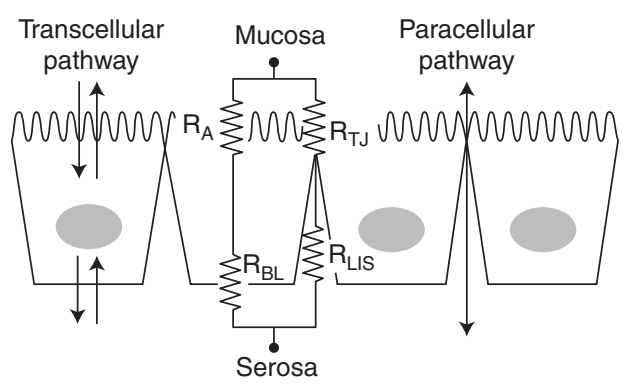

Figure 1. Electrical circuit model of the series and paracellular resistances across trans- and paracellular pathways of an epithelial cell monolayer. Transcellular transport is controlled by transporters in the apical and basolateral surfaces. The resistance of these series elements is typically much higher than that of the parallel elements of the paracellular pathway. Thus, the overall resistance of an epithelium is defined by $\mathrm{R}_{\mathrm{TJ}}$, which is defined by the composition of claudins in the tight junction (TJ). 
Physiology and Function of the Tight Junction

Table 1. Electrical characteristics of some epithelia and endothelia

\begin{tabular}{|c|c|c|c|c|}
\hline Tissues $^{\mathrm{a}}$ & Species & $\mathrm{R}_{\text {cell }} \Omega \times \mathrm{cm}^{2}$ & $\mathrm{R}_{\text {paracellular }} \Omega \times \mathrm{cm}^{2}$ & $\mathrm{P}_{\mathrm{Na}} / \mathrm{P}_{\mathrm{Cl}} \mathrm{b}^{\mathrm{b}}$ \\
\hline Proximal tubule & $\operatorname{dog}$ & - & $6-7$ & 1.4 \\
\hline Gallbladder & rabbit & 229 & 21 & 3.3 \\
\hline Duodenum & rat & - & 98 & - \\
\hline Jejunum & rat & 67 & 51 & 10.0 \\
\hline Ileum & rabbit & 115 & 100 & 2.5 \\
\hline \multirow[t]{3}{*}{ Distal colon } & rabbit & 730 & 385 & 0.6 \\
\hline & mouse surface & 132 & 3,200 & - \\
\hline & crypt & 429 & - & - \\
\hline Brain endothelium & & 1,300 & & \\
\hline Gastric fundus & Necturus & 2,826 & 10,573 & - \\
\hline Urinary bladder & rabbit & 160,000 & 300,000 & - \\
\hline \multicolumn{5}{|l|}{ Cell lines ${ }^{c}$} \\
\hline Caco-2 & human colon & $125-250$ & - & 3.0 \\
\hline LLC-PK $_{1}$ & pig prox. tubule & 100 & - & 0.6 \\
\hline MDCK & $\operatorname{dog}$ & $60-4000$ & - & 10.0 \\
\hline
\end{tabular}

${ }^{\mathrm{a}}$ All values can be found in Powell (Powell 1981) or Crone (Crone and Christensen 1981).

${ }^{\mathrm{b}}$ Permeability ratio of $\mathrm{Na}^{+}$versus $\mathrm{Cl}^{-} . \mathrm{P}_{\mathrm{Na}} / \mathrm{P}_{\mathrm{Cl}}$ in free solute is 0.66 . Paracellular pathways with ratios above this value are more permeable for $\mathrm{Na}^{+}$than $\mathrm{Cl}^{-}$, i.e., cation-selective.

${ }^{c}$ Values for cell lines are the personal observations of Dr. C. Van Itallie. Modified, with permission, from Van Itallie and Anderson (2004) (C) American Thoracic Society).

( $\mathrm{R}_{\text {apical }}$ and $\left.\mathrm{R}_{\text {basolateral }}\right)$, it is the $\mathrm{TJ}\left(\mathrm{R}_{\mathrm{TJ}}\right)$ that determines whether the transepithelial resistance is high or low (Fig. 1). Theoretically, the lateral intercellular space $\left(\mathrm{R}_{\text {lis }}\right)$ could contribute a resistance in series with the tight junction, but there is little evidence that this is physiologically significant.

TER differs by several orders of magnitude between so-called "tight" and "leaky" epithelia (Table 1). For example, the epithelium of the mammalian proximal tubule is only about $6 \Omega \cdot \mathrm{cm}^{2}$ compared with the toad urinary bladder at 300,000 $\Omega \cdot \mathrm{cm}^{2}$ (Powell 1981; Van Itallie and Anderson 2006). The relevance of TER is that epithelia with "tight" tight junctions can maintain the high electrochemical gradients produced by active transcellular transport. This configuration is used to produce either highly concentrated or diluted secretions, as in the distal nephron, which can produce urine with osmolarity several fold higher or lower than plasma. In contrast, epithelia with "leaky" tight junctions move large amounts of isosmotic fluids. A good example is provided by the human gastrointestinal tract, which secretes and then reabsorbs about $10 \mathrm{~L}$ of fluid each day (Boron and Boulpaep 2005). Most of the gastrointestinal track is of low TER, except in the distal colon where steeper electrochemical gradients are required to reabsorb $\mathrm{NaCl}$ and water and form solid stool.

Study of leaky epithelia revealed another interesting and variable property, namely that tight junctions (TJs) have ionic charge selectivity. Charge selectivity is most relevant in leaky tight junctions where higher amounts of ions flow. Almost all leaky TJs show a preference for $\mathrm{Na}^{+}$over $\mathrm{Cl}^{-}$, and the permeability ratio (expressed as $\mathrm{P}_{\mathrm{Na}} / \mathrm{P}_{\mathrm{Cl}}$ ) ranges from about 10 to 0.1 among different epithelia and experimental cultured cell models (Table 1). This represents only a modest ability to discriminate compared with membrane ion channels. For comparison, some amiloride-sensitive $\mathrm{Na}^{+}$ channels (ENaC) show a 1000-fold preference for $\mathrm{Na}^{+}$over $\mathrm{K}^{+}$, an identically charged ion of similar size (Hille 2001). However, even a 10-fold cation to anion discrimination has significant physiologic implications. For example, epithelia that secrete salt and water initiated by an apical $\mathrm{Cl}^{-}$channel (such as CFTR in the airway, lacrimal glands, etc.) are found to have a threefold to 10-fold preference for $\mathrm{Na}^{+}$over $\mathrm{Cl}^{-}$. This allows paracellular passage of $\mathrm{Na}^{+}$ 
to follow secreted $\mathrm{Cl}^{-}$while relatively discriminating against back diffusion of the $\mathrm{Cl}^{-}$, which would defeat the ability to secrete $\mathrm{NaCl}$ and water.

The TJ was first visualized at the ultrastructural level in 1963 by Farquhar and Palade (Farquhar and Palade 1963). They were able for the first time to resolve the apical junction complex (terminal bar) into three morphologically discrete contacts from the apical-most occluding or TJ (zonula occludens) followed by the cadherin-based adherens junction and the more basally positioned desmosomes. Gap junction plaques are also commonly found within the TJ contacts. The TJ zone is formed by a variable number of close cell-cell contacts or "kisses," which range from a single continuous contact (e.g., some endothelial cells) to a half dozen ( jejunum) or dozens of contacts in the most extreme mammalian example (Sertoli cells). Subsequent visualization of the tight junction in freeze fracture EM images revealed that membrane kisses correspond to continuous rows of $10-\mathrm{nm}$ transmembrane particles, which are presumed to contain an oligomerized array of claudins. The physical barrier to paracellular diffusion occurs where rows of particles adhere and seal across the intercellular space. The existence of multiple strands is speculated to provide redundancy to the barrier. Although there is no experimental proof for this idea, it seems very reasonable to assume that multiple barriers in series would provide a fail-safe barrier during cell dynamics, such as when cells move relative to each other (Matsuda et al. 2004) or single cells leave the epithelia sheet during apoptosis (Madara et al. 1980). In the early 1970s, Philippe Claude proposed that TER has a logarithmic dependence on the number of strands in series, the so-called Claude hypothesis (Claude 1978). By a quirk of etymology, the Claude hypothesis is no longer accepted but the TER is now thought to depend on the profile of different claudins expressed.

To summarize, the field of TJs before the discovery of claudins was well described at a physiologic level. Comparing epithelia: Cell-specific TJ barriers allow the passage of varying levels of electrical current and noncharged solutes. Based on how paracellular ion selectivity varied with extracellular $\mathrm{pH}$, several insightful investigators in the 1970s had already proposed that the junction was created by pore-forming proteins with variable side-chain chemistries (Wright and Diamond 1968). A major transformation (in fact a resurrection) of the field occurred with discovery of the barrier and pore-forming proteins.

\section{TRANSMEMBRANE TJ PROTEINS AND THE CLAUDIN FAMILY}

The TJ has a surprisingly complex protein composition compared with other cell-cell junctions and is composed of at least 40 different proteins (Schneeberger and Lynch 2004; Gonzalez-Mariscal et al. 2003; Yamazaki et al. 2008). This complexity is a consequence of its many interrelated roles in cell polarity (Cereijido et al. 1998), signaling (GonzalezMariscal et al. 2008; Van Itallie and Anderson 2006), transcriptional regulation, and cell cycle (Balda and Matter 2003; Tsukita et al. 2008) and vesicle trafficking (Yeaman et al. 2004), in addition to creating the paracellular barrier. Excellent reviews of the cytoplasmic plaque proteins and nonclaudin transmembrane proteins can be found in Gonzalez-Mariscal et al. (2003) and Schneeberger and Lynch (2004). A recent proteomics study suggests that there are many more transmembrane proteins yet to be characterized (Yamazaki et al. 2008). The role of these other transmembrane proteins remains an active area of investigation; however, all current evidence supports a central role for claudins in defining electrical resistance and permselectivity.

\section{Nonclaudin Transmembrane Proteins}

In addition to claudin family members, there are currently three other transmembrane proteins localized within the adhesive barrier strands and which in theory might directly influence the barrier. Occludin (Furuse et al. 1993) and tricellulin (Ikenouchi et al. 2005) are related tetraspanning proteins of currently unknown 
function. Occludin knockdown (KD) cell lines (Yu et al. 2005) and even knockout (KO) mice have no definable barrier defects (Saitou et al. 2000). KD cell lines reform TJs more slowly after a Ca-switch and have elevated levels of active GTP-bound RhoA (Yu et al. 2005), leading to speculation of a role for occludin in cytoskeletal dynamics. KO mice have a collection of defects, but there are no obvious barrier changes when assessed by TER, steadystate potential difference, electrical impedance, or solute tracer flux (Schulzke et al. 2005). An alternative role for occludin in coordinating transmembrane signaling is suggested by the findings that it binds the TGF- $\beta$ type III receptor (Barrios-Rodiles et al. 2005) and manipulation of occludin in cultured cells affects Raf-1 signaling (Wang et al. 2005). Human tricellulin mutations result in a nonsyndromic form of deafness by an unknown mechanism (Riazuddin et al. 2006). There is a third protein in the human database homologous to occludin and tricellulin (MARVELD3, Genebank ID: 91862, personal observation). Perhaps functional redundancy among these proteins has obscured the role of the individual proteins. Finally, there are several IgG superfamily members within the stand contacts (CAR [Coyne and Bergelson 2005], CLP24 [Kearsey et al. 2004]); the best studied being JAM-A, which appears to stabilize the barrier (Bazzoni 2003). In support of this idea, KD of JAM-A in cultured epithelia monolayers is reported to induce leakiness for large paracellular tracer molecules (Liu et al. 2000). The intestinal epithelium of JAM-A KO mice is extremely sensitive to disruption in inflammatory models (Laukoetter et al. 2007; Vetrano et al. 2008).

\section{The Claudin Family}

The first claudins were discovered in 1998 by Furuse and Tsukita through traditional biochemical fractionation of membrane fractions from liver (Furuse et al. 1998). When expressed in claudin-null fibroblasts, claudins formed the characteristic linear strands of $10-\mathrm{nm}$ particles observed in TJs and conferred cell-to-cell
Physiology and Function of the Tight Junction

adhesion (Kubota et al. 1999). Mammalian claudins range from 20 to $27 \mathrm{kDa}$ and have four transmembrane helices: a short internal amino-terminal sequence (2-6 residues), two extracellular domains (loop 1 is $49-52$ residues and loop 2 is $16-33$ residues), and a longer and more variable cytoplasmic tail (21-63 residues) (Fig. 2B). Claudins are recognized by the signature residues $\mathrm{W}-\mathrm{GLW}-\mathrm{C}-\mathrm{C}$ in the first extracellular loop, although the function of these highly conserved residues remains unknown (Fig. 2A). The carboxy-termini of claudins contain a PDZ-binding motif and several have been shown to bind PDZ domains within the cytoplasmic scaffolding proteins ZO-1,-2, and -3 (Itoh et al. 1999), MUPP1 (Hamazaki et al. 2002; Jeansonne et al. 2003) and PATJ (Roh et al. 2002). ZO-1 has three PDZ domains, MUPP1 13, and PATJ 10, suggesting that there exists a dense Velcro-like trap of PDZ interactions under the claudin strands. However, there is actually no clear evidence that PDZ binding is required for targeting of claudins to the $\mathrm{TJ}$ in epithelial cells or for claudins to confer physiologic effects when expressed in cultured cell models. In a single case, when claudin- 1 was expressed in cultured MDCK cells without a functional PDZ motif, this resulted in ectopic strands on the lateral cell surface (McCarthy et al. 2000).

Claudins are members of the much larger pfam00822 or PMP-22/EMP/MP20/Claudin family. These claudin relatives share the tetraspanning topology and W-GLW-C-C signature motif in the first extracellular loop. Beyond these structural similarities, their functions appear highly divergent and only some are believed to create intercellular barriers. The most homologous to claudins are MP20 (eye lens specific membrane protein) (Steele et al. 1998); epithelial membrane proteins (EMP-1, $-2,-3$ ) (Jetten and Suter 2000), and peripheral myelin protein 22 (PMP22) (Notterpek et al. 2001). PMP-22 is highly expressed in Schwann cells and required for myelin formation (Bronstein 2000). Several forms of human peripheral polyneuropathies arise from PMP22 mutations, deletions, or gene duplications (Brancolini et al. 2000) (Table 2). Surprisingly, 
J.M. Anderson and C.M. Van Itallie

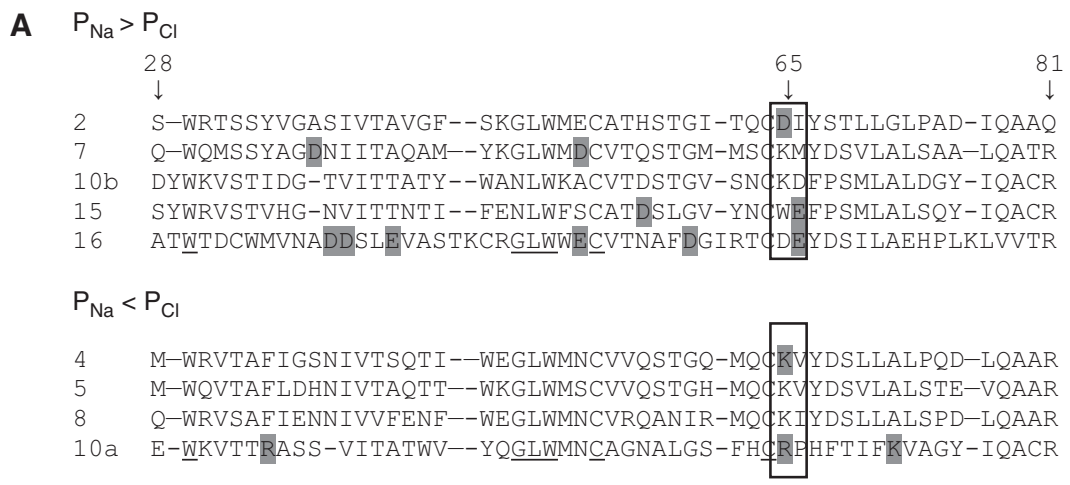

B Electrostatic

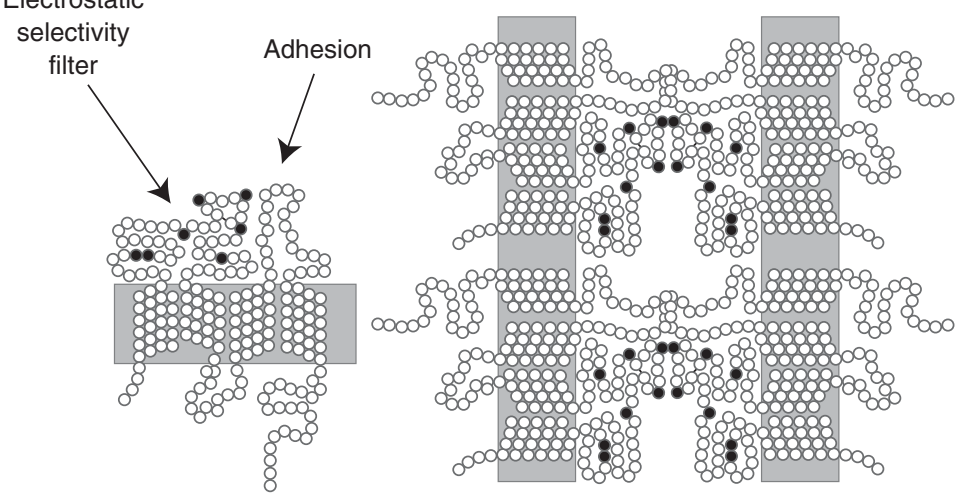

Figure 2. (A) The first extracellular loops of several claudins, which have been tested for charge selectivity. Residue numbering is based on the sequence of claudin-2. Numerous shaded positions alter selectivity when mutated. Alternatively, the boxed residues around residue 65 have been suggested to be the most critical in determining selectivity. Signature W-GLW-C-C residues are underlined. (B) Conceptual model of the claudin-based TJ barrier. The first extracellular loop contains the electrostatic selectivity filter of the pore and the second loop the cell-cell adhesion sites. In an unknown way, claudin monomers assemble into continuous strands within each cell membrane and adhere across the intercellular space to create a barrier with size and charge-selective pores.

although PMP22 is only $19 \%$ identical to human claudin-1, it has been found in tight junctions in liver, intestine (Notterpek et al. 2001), and the blood-brain barrier (Roux et al. 2004), and when expressed in MDCK cells, it increases TER (Roux et al. 2005). More distant members of the pfam00822 family include the subfamily of $\gamma$ subunits of voltage-dependent calcium channels. These are required for proper membrane delivery of channel complexes (Tomita et al. 2004). One of these, stargazin, which is an AMPA receptor regulator, was recently shown to mediate cellcell adhesion when expressed in fibroblasts, suggesting some distantly related members of this family may have retained claudin's cellcell adhesive property (Price et al. 2005).

Study of invertebrate claudins supports a role in barrier formation, although unlike vertebrates, they lack tight junctions. Their epithelial barriers are formed by septate junctions with wide intercellular gaps, very different from the near fusions at tight junctions. Drosophila has six claudin sequences, two of which, Megatrachea (Mega) (Behr et al. 2003) and Sinuous (Sinu) (Wu et al. 2004) are located at septate junctions; mutations in Mega disrupt the barrier. Mutations of either claudin also result in developmental defects in the size and shape of the tracheal epithelium. 
Physiology and Function of the Tight Junction

Table 2. Genetic diseases of tight junction proteins

\begin{tabular}{|c|c|c|c|}
\hline Gene & Disease & Pathology/Mechanism & Ref. \\
\hline Cldn-1 & Ichthyosis, sclerosing cholangitis & Affects skin and bile ducts & (Hadj-Rabia et al. 2004) \\
\hline Cldn-14 & Nonsyndromic deafness, DFNB29 & Cochlear hair cell degeneration & (Ben Yosef et al. 2003) \\
\hline \multicolumn{4}{|l|}{ Cldn-16 } \\
\hline Human & $\mathrm{HHNC}^{\mathrm{a}}$ & Defective renal $\mathrm{Mg}^{++}$reabsorption & (Simon et al. 1999) \\
\hline Bovine & interstitial nephritis & & (Hirano et al. 2000) \\
\hline Cldn-19 & Renal $\mathrm{Mg}^{++}$loss and vision loss & Similar to Cldn-16 & (Konrad et al. 2006) \\
\hline \multirow[t]{4}{*}{ PMP22 } & Peripheral polyneuropathies & Demyelinization & $\begin{array}{l}\text { (Gabreels-Festen and } \\
\text { Wetering 1999) }\end{array}$ \\
\hline & $\mathrm{HNPP}^{\mathrm{b}}$ & Gene deletion & \\
\hline & Charcot-Marie-Tooth Type 1A & Gene duplication & \\
\hline & Dejerine-Sottas syndrome & Point mutations & \\
\hline $\mathrm{ZO}-2$ & Familial hypercholanemia & Defective PDZ-claudin binding & (Carlton et al. 2003) \\
\hline Tricellulin & Nonsyndromic deafness & Loss of ZO-1 binding & (Riazuddin et al. 2006) \\
\hline
\end{tabular}

Five claudin-like sequences have been identified in Caenorhabditis elegans (Asano et al. 2003) and RNAi-mediated ablation of claudinlike protein 1 disrupted the barrier between epithelial cells of the hypodermis.

\section{Claudin Cell-Cell Adhesion and Assembly}

There remains almost no information about how individual claudins assemble into higher order structures to create $10-\mathrm{nm}$ membrane particles, polymerize into the strands observed in freeze-fracture EM, or adhere across the cell-cell interspace. Currently, two papers suggest claudins, like connexins in the gap junction, form hexamers. This is based on a study of human claudin-4 expressed in insect cells (Mitic et al. 2003) and on purified native MP20, the distant claudin relative found in the lens (Jarvis and Louis 1995). There is consistent evidence that claudins can form homotypic adhesive plaques, and two studies provide evidence that this homotypic cell-cell adhesion can occur through residues in the center of the second extracellular loop (Daugherty et al. 2007; Piontek et al. 2007). Molecular modeling of claudin-5 complemented by mutagenesis suggests that adhesion requires an interaction of complementing hydrophobic residues along a helix in the center of the second loop
(Piontek et al. 2007). A model of the barrier in Figure $2 \mathrm{~B}$ is based on evidence that claudins are cell-to-cell adhesion molecules and form small pores through the barrier, but there is currently insufficient evidence to speculate on how they oligomerize to form the particles seen in freeze fracture EM images.

Most cell types express several different claudins, which assemble into the same adhesive strands, yet the generality of heterotypic binding across the intercellular space remains an unresolved question. There is limited evidence that a subset of claudins can interact heterotypically across cell contacts; for example, claudin-1 can bind claudin-3 but not claudin-2 (Furuse et al. 1999), but there is currently no information that allows generalizations about which claudins can interact or if adhesion involves additional proteins (Fig. 2A,B). Some claudins are observed to coimmunoprecipitate with a list of proteins (e.g., claudin-7 with EpCAM [Le Naour and Zoller 2008]; claudin-11 with $\beta 1$ integrin and tetraspanins [Tiwari-Woodruff et al. 2001]), although the biologic implications remain unknown. Further understanding of how various functions (selectivity, adhesion, and assembly) are organized within the protein is severely limited by a current lack of structural information. 


\section{PERMSELECTIVITY AND THE TWO PATHWAY MODEL: SMALL SELECTIVE PORES AND NONSELECTIVE BREAKS}

The term "permselectivity" is used to describe variations among TJs in electrical resistance, ionic charge and size discrimination, and the magnitude of solute permeability (Table 1) (Powell 1981). TER and solute flux are in part a function of cell geometry. For example, a monolayer with smaller cells has more cellcell contact length per unit area through which electrical current and solutes can pass. Assuming the same claudins are expressed, a monolayer with smaller cells will show lower TER and higher solute flux. Geometry of the individual cell-cell contacts can also affect TJ length per unit area. Some cells touch with straight junction contacts, whereas others make elaborate interdigitations. For example, those between cells in mammalian thin ascending limb of the loop of Henle are extremely redundant, which increases $\mathrm{TJ}$ length per unit area of the epithelium at least 10-fold over strength contacts. Presumably, this arrangement enhances the space for paracellular transport without requiring larger epithelium. However, at the protein level, it is now recognized that a critical determinant of permselectivity is the profile and levels of different claudins expressed in a given tight junction.

\section{Size}

In general, description of paracellular size selectivity in the cell biology and physiology literature has been rather imprecise, in contrast to studies in the pharmaceutical literature, which have specifically focused on how transepithelial drug absorption is influenced by solute size and chemistry. Research in the former fields is often concerned only with TJ assembly or disassembly, rather than with subtleties of the permselectivity. In most studies, a single tracer size is used to report paracellular flux, which limits the ability to determine experimental changes in the size-dependence of permeability. Tracer charge is usually ignored as is a possible transcellular contribution from transcytosis. These subtleties are important because information about alterations in size and charge dependence may have important pathologic implications, for example in determining if specific cytokines or bacterial toxins might have increased access across the paracellular space.

Now that the actual barrier-forming proteins have been discovered, it is instructive to characterize permeability as a continuous function of solute size (Watson et al. 2001; Watson et al. 2005; Van Itallie et al. 2008). This is performed by characterizing the permeability for solutes of progressively larger molecular radii. Apparent Permeability $\left[\mathrm{P}_{\mathrm{app}}=(d \mathrm{Q} / d t) /\right.$ (Concentration Gradient $\times$ Area)] takes into account the chemical driving force for each solute and surface area, and, unlike simple flux $(d Q / d t)$, can be compared among tissues and laboratories. When size profiling is performed using a noncharged solute like graded polyethylene polymers (PEGs), it becomes obvious that permeability has two components (Fig. 3). There is a higher capacity pathway with a steep size dependence for solutes less than about $4 \AA$ in radius (Knipp et al. 1997; Watson et al. 2001; Van Itallie et al. 2008). This pore-pathway shows ionic charge discrimination and its magnitude varies among epithelia. This is the pathway that carries most of the

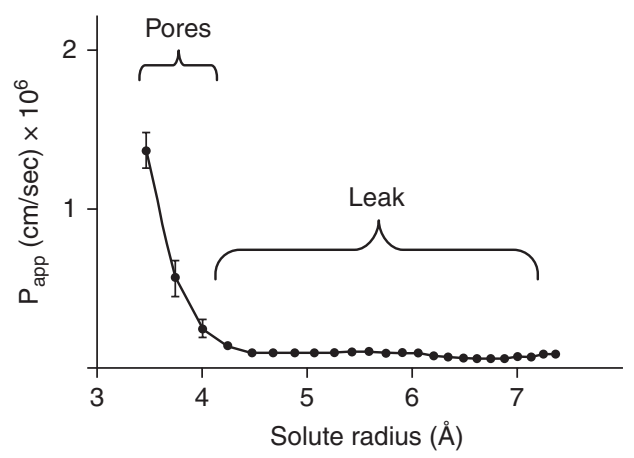

Figure 3. The two pathway model. Idealized data show the permeability of noncharged polyethylene glycol molecules of different sizes across an epithelium. The pathway for molecules below $4 \AA$ is formed by claudin pores that are size and charge selective. The pathway for molecule above $4 \AA$ in diameter shows no charge selectivity and appears to be defined by the status of cell-to-cell adhesion and the cytoskeleton. 
electrical current during physiologic transport and during experimentally imposed electrical field (reflected in the TER), thus its magnitude and charge selectivity are key determinants of physiologic transport. As described below, claudins confer the charge selectivity, but there is less information on what determines the magnitude of flux through the pores. However, different claudins may control the level of porosity because it has been observed that expression of claudin-2 in cultured epithelial cells selectively increases the permeability for solutes smaller than $4 \AA$, whereas claudins 4 and 18 do not (Van Itallie et al. 2008). In vivo, deletion of claudin-5 from mice results in a size-selective increase in permeability of TJs in blood vessels (Nitta et al. 2003). It is important to recognize that the permeability for noncharged and charged solutes are not necessarily directly correlated. Because pores in different epithelia can have different charge discrimination, one can observe an apparent paradox in which the solute permeability is very high but the ion permeability is very low (high TER). Taken together, the present data suggest that claudins create the system of small discriminating pores, and by an unknown mechanism regulate the magnitude of flux (Fig. 3).

Solutes that are larger than $4 \AA$ can also get through intact TJs. The magnitude of this component varies among epithelia and shows no charge discrimination (Knipp. et al. 1997; Artursson et al. 1993). The distinction between the pore and nonpore pathways has been overlooked in most of the literature because permeability is typically measured only by tracers, which are larger than the pores, namely mannitol ( $4.2 \AA$ in radius), inulin $(15 \AA)$, and a graded series of fluorescently labeled dextrans (4 kDa, $10 \mathrm{kDa}, 40 \mathrm{kDa}$, etc). This larger pathway is speculated to represent small temporary breaks in the otherwise continuous TJ contacts. Interestingly, flux through this pathway can be enhanced by proinflammatory cytokines without altering the pore pathway (Watson et al. 2005). The nonpore pathway is sensitive to cytoskeletal disruption (Bruewer et al. 2004; Ivanov et al. 2005) and any form of cellular injury (Nusrat
Physiology and Function of the Tight Junction

et al. 2000). There is significant evidence that the "intactness" of the TJ is controlled by cytoskeletal dynamics (Hartsock and Nelson 2008), myosin light chain activity (Ma et al. 2005), and any factor affecting cell homeostasis. As investigators dissect the role of individual proteins and signals in regulating the barrier, it will be useful to characterize barriers in terms of the pore and nonpore pathways.

\section{Claudin Charge Selectivity and TER}

All of the available data supports the idea that the first extracellular loop of claudins creates an "electrostatic selectivity filter," controlling overall resistance and charge selectivity of the small pores (Fig. 2). In contrast, admittedly limited data suggest that the second loop is involved in cell-cell adhesion (Blasig et al. 2006; Piontek et al. 2007). Charged amino acid side chains on the claudins limit similarly charged ions in solution without opposing permeability of oppositely charged ions. Most of these studies have been performed by expressing a single foreign claudin in the background of all the other claudins expressed in a cultured epithelial cell monolayer, most often MDCK and LLC-PK 1 cells or by siRNA knockdown of selected claudins (Hou et al. 2006). A change from the baseline TER and dilution potential (a measure of cation/anion selectivity) is interpreted to reveal selectivity of the transfected or silenced claudin compared with the background. These studies are somewhat qualitative. Lacking the electrophysiologic tools used to characterize membrane channels, such as patch clamping, it has been impossible to assign a specific conductance to individual claudins.

A total of 15 claudins have now been tested with good consensus. Claudins 2 (Furuse et al. 2001; Colegio et al. 2002; Amasheh et al. 2002) and 10 (Van Itallie et al. 2006) tend to make tight monolayers leakier. Claudins 1 (Inai et al. 1999; McCarthy et al. 2000), 4 (Van Itallie et al. 2001), 5 (Wen et al. 2004; Amasheh et al. 2005), 7 (Alexandre et al. 2005), 8 (Angelow et al. 2006; Yu et al. 2003; Jeansonne et al. 2003), 11 (Van Itallie et al. 2003), 14 (Ben Yosef et al. 2003), 15 (Colegio 
et al. 2003; Van Itallie et al. 2003), 16 (Hou et al. 2005; Ikari et al. 2008), 18 (Jovov et al. 2007), and 19 (Hou et al. 2008) tend to make leaky monolayers tighter. Claudins 2, 15 (Amasheh et al. 2002; Colegio et al. 2003), 16, and 19 (Hou et al. 2008) have a preference for cations over anions. Claudin-10a (Van Itallie et al. 2006) prefers anions. Where tested, the effect on TER is dose-dependent and each claudin reaches a saturating influence on TER (Van Itallie et al. 2001), although the reason for this is not clear. Most reports simply express the change in barrier permselectivity that results from the maximal induction level. Some studies suggest that the transfected claudin adds to those already present, whereas a single study convincingly shows that claudin-8 can replace endogenous claudin-2 (Yu et al. 2003). Potencies vary, with claudins 14 (Ben Yosef et al. 2003) and 18 (Jovov et al. 2007) producing the electrically tightest barriers. A single study has simultaneously expressed two different claudins, showing that claudins 16 and 19 exert properties in a cooperative and not just additive fashion, consistent with the idea that claudins might form heterotypic pores (Hou et al. 2008).

There is a general relationship between the chemistry of the first loop and charge selectivity (Fig. 2A). However, the relative influence of specific positions is still under debate. For example, claudin-16 has the highest proportion of negatively charged residues (Fig. 2A, shaped positions) and when expressed in cultured epithelial cell monolayers, results in a strong enhancement in permeability for $\mathrm{Na}^{+}$and $\mathrm{Mg}^{++}$but has no affect on $\mathrm{P}_{\mathrm{Cl}}$ (Hou et al. 2005). In the opposite direction, claudin-10a has more basic residues and reduces $\mathrm{P}_{\mathrm{Na}}$, while simultaneously increasing $\mathrm{P}_{\mathrm{Cl}}$ (Van Itallie et al. 2006). Each claudin has shown a signature pattern of whether it will increase or decrease TER and increase, decrease, or not alter the individual $\mathrm{P}_{\mathrm{Na}}$ and $\mathrm{P}_{\mathrm{Cl}}$. The ability to increase TER can be based on limiting permeability for just cations (claudin-4 [Van Itallie et al. 2001]) or both cations and anions (claudin-7 [Alexandre et al. 2005]). There is a reassuring correlation between the physiology of particular tissues, the claudins they express, and the physiology of those claudin as determined experimentally (Holmes et al. 2006). This is best documented along the nephron, where TER and ion selectivity are very well documented. For example, "leaky" claudin-2 is the dominant form in the leaky proximal tubule and is excluded from tighter segments; "tight" claudin -4 and -8 are restricted to the tight collecting ducts (Angelow et al. 2008).

The role of individual positions in influencing charge selectivity has most often been tested by expressing charge-reversing mutations. This approach has led to the conclusion that positions along much of the first loop can influence selectivity and thus this loop is folded to line the pore space through which soluble ions pass. This has been most extensively studied for claudins 15 (Van Itallie et al. 2003) and 16 (Hou et al. 2005). In the case of claudin-15, three widely spaced and negatively charged residues were sequentially reversed and shown to have additive effects (Van Itallie et al. 2003). The "distributed filter" model has been criticized because it is based on introducing abnormal charges rather than simply neutralizing them. Extensive characterization of charge-neutralizing mutations of claudin-2 convincingly showed that the only charged residue that provides the high $\mathrm{P}_{\mathrm{Na}}$ is the aspartic acid at position 65 (Fig. 2A) (Yu et al. 2009). Resolution of the mechanism of selectivity must await high-resolution structural information.

The TJ pore is slightly wider than that of transmembrane pores and consequently shows less ionic discrimination. For comparison, some $\mathrm{Na}^{+}$channels (ENaC) show a permeability ratio for $\mathrm{Na}^{+}$to $\mathrm{K}^{+}\left(\mathrm{P}_{\mathrm{Na}} / \mathrm{P}_{\mathrm{K}}\right)$ as high as 1000 to 1 (Hille 2001). In contrast, claudin pores show almost no discrimination between $\mathrm{K}^{+}$and $\mathrm{Na}^{+}$and the $\mathrm{P}_{\mathrm{Cl}} / \mathrm{P}_{\mathrm{Na}}$ ratio ranges only from about 10 to 0.1 when compared among various in vivo epithelia and cultured cell monolayers. Membrane channels are of a size where the associated water molecules must be stripped off so the ion can fit through the pore (Hille 2001; Yu et al. 2009). The modest ability of TJs in MDCK cells to 
discriminate among the alkali metal cations $(\mathrm{K}>\mathrm{Rb}>\mathrm{Na}>\mathrm{Li}>\mathrm{Cs}$, so-called Eisenman selectivity sequence V-VIII) does actually suggest that they are being partially dehydrated as they pass through the pore. The observed Eisenman sequence is slightly different from the rank order of their free mobilities in solution, leading to the conclusion that the pore radius is about $3.6 \AA$ (Yu et al. 2009). This is concordant with the $4 \AA$ radius estimated using noncharged solutes (Watson et al. 2001). It is remarkable that this degree of size and charge selectivity can be maintained while cells in an epithelial sheet continuously move relative to one another.

Several claudins have now been deleted from mice and the resulting phenotypes are consistent with a barrier role for claudins 1 (Ladwein et al. 2005), 5 (Nitta et al. 2003), 11 (Gow et al. 2000), 14 (Ben Yosef et al. 2003), and 15 (Tamura et al. 2008), although the phenotypes are not easily explained as changes in permselectivity. In contrast, deletions of 16 (Himmerkus et al. 2008) and 19 (Hou et al. 2008) phenocopy their human disease mutants and are more easily explained as ion selectivity defects, as described in the following section.

In zebrafish, reduction in claudin- 15 through morphlino treatment produces a developmental intestinal defect, which very likely results from loss of ion transport selectivity (Bagnat et al. 2007). In the absence of claudin-15, the gut remains as multiple lumens, which fail to fuse. It is proposed that active ion and water secretion is required for the lumens to enlarge, come into contact, and fuse. In the absence of claudin-15, there may be a back leak of $\mathrm{Na}^{+}$, preventing fluid accumulation and expansion. Interestingly, claudin-15 KO mice develop a megaintestine, but this phenotype appears to be a proliferation and not a permeability defect (Tamura et al. 2008).

\section{Claudin-16 Mutants and Other Inherited Diseases of Tight Junction Proteins}

Currently, there are seven human diseases known to be caused by mutations in genes
Physiology and Function of the Tight Junction

encoding tight junction proteins (Table 2). The basis for ZO-2 (Carlton et al. 2003) and tricellulin-based defects (Riazuddin et al. 2006) remains unclear, but the phenotypes of several of the recessive claudin mutants provide additional evidence that claudins provide selectivity for the barrier. We describe the claudin-16 defect in some detail because it provides the best evidence that claudins in vivo create ion selective pores.

The first disease-causing claudin mutation was identified through positional cloning of the locus responsible for a rare form of renal magnesium loss, hypomagnesemia hypercalcemia with nephrocalcinosis (HHNC) (Simon et al. 1999; Kaushansky et al. 2007). Patients with this defect show increased urinary loss of $\mathrm{Mg}^{++}$and $\mathrm{Ca}^{++}$, and reduced plasma $\mathrm{Mg}^{++}$ levels, leading to weakness and seizures. The gene responsible encodes claudin-16 (originally referred to a Paracellin-1). Claudin-16 is highly restricted to the thick ascending limb of the loop of Henle, the segment of the nephron most involved in reabsorbing filtered $\mathrm{Mg}^{++}$. Other claudins are also expressed in the same TJs. Paracellular reabsorption is driven by an intralumenal positive electrical potential with respect to the peritubular interstitium. These observations led to an initial hypothesis that claudin-16 is a $\mathrm{Mg}^{++}$pore and when absent, $\mathrm{Mg}^{++}$remains in the tubule and is lost in the urine. When expressed in cultured monolayers, wild-type claudin-16 does form a highly cationselective pore (Hou et al. 2005). Consistent with the electrostatic claudin pore model, the first loop contains many negatively charged residues (Fig. 2), and neutralizing mutations reduce cation permeability (Hou et al. 2005). Many of the human mutations are missense mutations, which fail to traffic properly to the plasma membrane when expressed in cultured cell models (Kausalya et al. 2006) suggesting the defect results from the selective absence of claudin-16, leaving other claudins to define the barrier's ion selectivity. Recently, mutations in the human claudin-19 gene were shown to cause renal $\mathrm{Mg}^{++}$wasting by a very similar mechanism. In addition, claudin-19 is expressed in the retina and affected individuals 
have defects in retinal development and vision loss (Konrad et al. 2006) (Table 2).

The Mg-pore model is probably too simplistic. The intralumenal positive potential driving $\mathrm{Mg}^{++}$results from a paracellular back diffusion of $\mathrm{Na}^{+}$down its concentration gradient into the lumen. If $\mathrm{Na}^{+}$entry is limited in the absence of claudin-16 pores, there would be a reduced electrical gradient to drive $\mathrm{Mg}^{++}$out. Although this can not be tested in humans, study of isolated perfused nephron segments from claudin-16 KO mice is consistent with a defect in $\mathrm{Na}^{+}$permeability (Himmerkus et al. 2008). Whatever the full explanation, claudin-16 is clearly a cation pore and HHNC remains the best example of a disease caused by an ion-selective TJ defect.

It is tempting to also explain hearing loss in the human claudin-14 mutants as an ion selectivity defect, but the evidence is only circumstantial. Claudin-14 is expressed in TJs lining the intrachoclear space, which contains fluid uniquely high in $\mathrm{K}^{+}$. This high gradient promotes rapid entry of $\mathrm{K}^{+}$into the outer hair cells; this is required for their depolarization during acoustic mechanotransduction. Other forms of deafness are caused by mutations in the transporters that normally secrete $\mathrm{K}^{+}$ into this space, suggesting that the loss of claudin-14 might cause deafness by allowing the $\mathrm{K}^{+}$gradient to dissipate. In fact, when claudin-14 is expressed in cultured MDCK cells, the junctions become very tight by specifically restricting cation permeability (Riazuddin et al. 2006). Finally, claudin-1 mutation results in neonatal ichthyosis-sclerosing cholangitis syndrome (NISCH), but whether this pathophysiology results from a permeability defect is unclear (Hadj-Rabia et al. 2004). Although claudin-1 is very widely expressed among all epithelia, it is difficult to rationalize why patients with these mutations develop predominately a scaling skin disease and obliteration of their bile ducts.

\section{CONCLUSION}

Significant progress has been made over the past decade in understanding the role of claudins in regulation of TER and paracellular ionic selectivity. In addition, the recognition of the existence of two pathways for paracellular solute flux should allow a more sophisticated analysis of the roles individual TJ proteins play in physiologic and pathologic regulation of permeability of nonionic solutes. However, further insights are hampered by the lack of a three-dimensional model of TJ structure. Studies on the synaptic junction may provide clues and methods for studying TJ organization, but ultimately we will need structural information about the integral membrane proteins of the TJ to ask informative questions about how this complex is organized and physiologically regulated.

\section{ACKNOWLEDGMENTS}

This work was supported by grants from the National Institutes of Health, DK45134 (JMA, CVI), P30 DK034987, and DK61397 (JMA).

\section{REFERENCES}

Alexandre MD, Lu Q, Chen YH. 2005. Overexpression of claudin-7 decreases the paracellular $\mathrm{Cl}^{-}$conductance and increases the paracellular $\mathrm{Na}^{+}$conductance in LLC-PK1 cells. J Cell Sci 118: 2683-2693.

Amasheh S, Meiri N, Gitter AH, Schoneberg T, Mankertz J, Schulzke JD, Fromm M. 2002. Claudin-2 expression induces cation-selective channels in tight junctions of epithelial cells. J Cell Sci 115: 4969-4976.

Amasheh S, Schmidt T, Mahn M, Florian P, Mankertz J, Tavalali S, Gitter AH, Schulzke JD, Fromm M. 2005. Contribution of claudin- 5 to barrier properties in tight junctions of epithelial cells. Cell Tissue Res 321: 89-96.

Angelow S, Ahlstrom R, Yu AS. 2008. Biology of claudins. Am J Physiol Renal Physiol 295: F867-F876.

Angelow S, Kim KJ, Yu AS. 2006. Claudin-8 modulates paracellular permeability to acidic and basic ions in MDCK II cells. J Physiol 571: 15-26.

Artursson P, Ungell AL, Lofroth JE. 1993. Selective paracellular permeability in two models of intestinal absorption: Cultured monolayers of human intestinal epithelial cells and rat intestinal segments. Pharm Res 10: 1123-1129.

Asano A, Asano K, Sasaki H, Furuse M, Tsukita S. 2003. Claudins in Caenorhabditis elegans: Their distribution and barrier function in the epithelium. Curr Biol 13: 1042-1046.

Bagnat M, Cheung ID, Mostov KE, Stainier DY. 2007. Genetic control of single lumen formation in the zebrafish gut. Nat Cell Biol 9: 954-960.

Balda MS, Matter K. 2003. Epithelial cell adhesion and the regulation of gene expression. Trends Cell Biol 13: 310-318. 
Barrios-Rodiles M, Brown KR, Ozdamar B, Bose R, Liu Z, Donovan RS, Shinjo F, Liu Y, Dembowy J, Taylor IW, et al. 2005. High-throughput mapping of a dynamic signaling network in mammalian cells. Science 307: 16211625.

Bazzoni G. 2003. The JAM family of junctional adhesion molecules. Curr Opin Cell Biol 15: 525-530.

Behr M, Riedel D, Schuh R. 2003. The claudin-like megatrachea is essential in septate junctions for the epithelial barrier function in Drosophila. Dev Cell 5: 611-620.

Ben Yosef T, Belyantseva IA, Saunders TL, Hughes ED, Kawamoto K, Van Itallie CM, Beyer LA, Halsey K, Gardner DJ, Wilcox ER, et al. 2003. Claudin 14 knockout mice, a model for autosomal recessive deafness DFNB29, are deaf due to cochlear hair cell degeneration. Hum Mol Genet 12: 2049-2061.

Blasig IE, Winkler L, Lassowski B, Mueller SL, Zuleger N, Krause E, Krause G, Gast K, Kolbe M, Piontek J. 2006. On the self-association potential of transmembrane tight junction proteins. Cell Mol Life Sci 63: 505-514.

Boron W, Boulpaep EL. 2005. Medical physiology. A cellular and molecular approach, pp. 931-946. Elsevier Saunders, Philidelphia.

Brancolini C, Edomi P, Marzinotto S, Schneider C. 2000. Exposure at the cell surface is required for Gas3/ PMP22 to regulate both cell death and cell spreading: Implication for the Charcot-Marie-Tooth type $1 \mathrm{~A}$ and Dejerine-Sottas diseases. Mol Biol Cell 11: 2901-2914.

Bronstein JM. 2000. Function of tetraspan proteins in the myelin sheath. Curr Opin Neurobiol 10: 552-557.

Bruewer M, Hopkins AH, Hobert ME, Nusrat A, Madara JL. 2004. RhoA, Rac1, and Cdc42 exert distinct effects on epithelial barrier via selective structural and biochemical modulation of junctional proteins and F-actin. Am J Physiol Cell Physiol 287: C327-C335.

Carlton VE, Harris BZ, Puffenberger EG, Batta AK, Knisely AS, Robinson DL, Strauss KA, Shneider BL, Lim WA, Salen G, et al. 2003. Complex inheritance of familial hypercholanemia with associated mutations in TJP2 and BAAT. Nat Genet 34: 91-96.

Cereijido M, Anderson JM. 2001. Introduction: Evolution of ideas on the tight junction. In Tight junctions (ed. Cereijido M, Anderson JM), pp. 1-18. CRC Press, Boca Raton.

Cereijido M, Valdes J, Shoshani L, Contreras RG. 1998. Role of tight junctions in establishing and maintaining cell polarity. Annu Rev Physiol 60: 161-177.

Claude P. 1978. Morphological factors influencing transepithelial permeability: A model for the resistance of the zonula occludens. J Membr Biol 39: 219-232.

Colegio OR, Van Itallie CM, Mccrea HJ, Rahner C, Anderson JM. 2002. Claudins create charge-selective channels in the paracellular pathway between epithelial cells. Am J Physiol Cell Physiol 283: C142-C147.

Colegio OR, Van Itallie C, Rahner C, Anderson JM. 2003. Claudin extracellular domains determine paracellular charge selectivity and resistance but not tight junction fibril architecture. Am J Physiol Cell Physiol 284: C1346-C1354.

Coyne CB, Bergelson JM. 2005. CAR: Avirus receptor within the tight junction. Adv Drug Deliv Rev 57: 869-882.
Physiology and Function of the Tight Junction

Crone C, Christensen O. 1981. Electrical resistance of a capillary endothelium. J Gen Physiol 77: 349-371.

Daugherty BL, Ward C, Smith T, Ritzenthaler JD, Koval M. 2007. Regulation of heterotypic claudin compatibility. J Biol Chem 282: 30005-30013.

Diamond JM. 1977. Twenty-first Bowditch lecture. The epithelial junction: Bridge, gate, and fence. Physiologist 20: $10-18$.

Diamond JM. 1978. Channels in epithelial cell membranes and junctions. Fed Proc 37: 2639-2644.

Farquhar MG, Palade GE. 1963. Junctional complexes in various epithelia. J Cell Biol 17: 375-412.

Furuse M. 2009. Molecular basis of the core structure of tight junctions. Cold Spring Harb Perspect Biol 2: a002907.

Furuse M, Hirase T, Itoh M, Nagafuchi A, Yonemura $S$, Tsukita S, Tsukita S. 1993. Occludin - A Novel Integral Membrane-Protein Localizing at Tight Junctions. J Cell Biol 123: 1777-1788.

Furuse M, Fujita K, Hiiragi T, Fujimoto K, Tsukita S. 1998. Claudin-1 and -2: Novel integral membrane proteins localizing at tight junctions with no sequence similarity to occludin. J Cell Biol 141: 1539-1550.

Furuse M, Sasaki H, Tsukita S. 1999. Manner of interaction of heterogeneous claudin species within and between tight junction strands. J Cell Biol 147: 891-903.

Furuse M, Furuse K, Sasaki H, Tsukita S. 2001. Conversion of Zonulae occludentes from tight to leaky strand type by introducing claudin-2 into Madin-Darby Canine Kidney I cells. J Cell Biol 153: 263-272.

Gabreels-Festen A, Wetering RV. 1999. Human nerve pathology caused by different mutational mechanisms of the PMP22 gene. Ann NY Acad Sci 883: 336-343.

Gonzalez-Mariscal L, Betanzos A, Nava P, Jaramillo BE. 2003. Tight junction proteins. Prog Biophys Mol Biol 81: $1-44$.

Gonzalez-Mariscal L, Tapia R, Chamorro D. 2008. Crosstalk of tight junction components with signaling pathways. Biochim Biophys Acta 1778: 729-756.

Gow A, Southwood CM, Li JS, Pariali M, Riordan GP, Danias J, Bronstein JM, Brodie SE, Kachar B, Lazzarini RA. 2000. CNS myelin and sertoli cell tight junction stands are absent in osp/claudin 11-null mice. J Neurochem 74: S35.

Hadj-Rabia S, Baala L, Vabres P, Hamel-Teillac D, Jacquemin E, Fabre M, Lyonnet S, De Prost Y, Munnich A, Hadchouel $\mathrm{M}$, et al. 2004. Claudin-1 gene mutations in neonatal sclerosing cholangitis associated with ichthyosis: A tight junction disease. Gastroenterology 127: 1386-1390.

Hamazaki Y, Itoh M, Sasaki H, Furuse M, Tsukita S. 2002. Multi-PDZ domain protein 1 (MUPP1) is concentrated at tight junctions through its possible interaction with claudin-1 and junctional adhesion molecule. J Biol Chem 277: 455-461.

Hartsock A, Nelson WJ. 2008. Adherens and tight junctions: Structure, function and connections to the actin cytoskeleton. Biochim Biophys Acta 1778: 660-669.

Hille B. 2001. Ion channels of excitable membranes, pp. 573-574. Sinauer Associates, Sunderland, Massachusetts.

Himmerkus N, Shan Q, Goerke B, Hou J, Goodenough DA, Bleich M. 2008. Salt and acid-base metabolism in claudin-16 knockdown mice: Impact for the 
J.M. Anderson and C.M. Van Itallie

pathophysiology of FHHNC patients. Am J Physiol Renal Physiol 295: F1641-F1647.

Hirano T, Kobayashi N, Itoh T, Takasuga A, Nakamaru T, Hirotsune S, Sugimoto Y. 2000. Null mutation of PCLN-1/Claudin-16 results in bovine chronic interstitial nephritis. Genome Res 10: 659-663.

Holmes JL, Van Itallie CM, Rasmussen JE, Anderson JM. 2006. Claudin profiling in the mouse during postnatal intestinal development and along the gastrointestinal tract reveals complex expression patterns. Gene Expr Patterns 6: $581-588$.

Hou J, Paul DL, Goodenough DA. 2005. Paracellin-1 and the modulation of ion selectivity of tight junctions. J Cell Sci 118: 5109-5118.

Hou J, Gomes AS, Paul DL, Goodenough A. 2006. Study of claudin function by RNA interference. J Biol Chem 281: 36117-36123.

Hou J, Renigunta A, Konrad M, Gomes AS, Schneeberger EE, Paul DL, Waldegger S, Goodenough DA. 2008. Claudin-16 and claudin-19 interact and form a cationselective tight junction complex. J Clin Invest 118: 619-628.

Ikari A, Ito M, Okude C, Sawada H, Harada H, Degawa M, Sakai H, Takahashi T, Sugatani J, Miwa M. 2008. Claudin-16 is directly phosphorylated by protein kinase A independently of a vasodilator-stimulated phosphoprotein-mediated pathway. J Cell Physiol 214: $221-229$.

Ikenouchi J, Furuse M, Furuse K, Sasaki H, Tsukita S, Tsukita S. 2005. Tricellulin constitutes a novel barrier at tricellular contacts of epithelial cells. J Cell Biol 171: 939-945.

Inai T, Kobayashi J, Shibata Y. 1999. Claudin-1 contributes to the epithelial barrier function in MDCK cells. Eur J Cell Biol 78: 849-855.

Itoh M, Furuse M, Morita K, Kubota K, Saitou M, Tsukita S. 1999. Direct binding of three tight junction-associated MAGUKs, ZO-1, ZO-2 and ZO-3, with the $\mathrm{COOH}$ termini of claudins. J Cell Biol 147: 1351-1363.

Ivanov AI, Hunt D, Utech M, Nusrat A, Parkos CA. 2005. Differential roles for actin polymerization and a myosin II motor in assembly of the epithelial apical junctional complex. Mol Biol Cell 16: 2636-2650.

Jarvis LJ, Louis CF. 1995. Purification and oligomeric state of the major lens fiber cell membrane proteins. Curr Eye Res 14: 799-808.

Jeansonne B, Lu Q, Goodenough DA, Chen YH. 2003. Claudin-8 interacts with multi-PDZ domain protein 1 (MUPP1) and reduces paracellular conductance in epithelial cells. Cell Mol Biol(Noisy-le-grand) 49: 13-21.

Jetten AM, Suter U. 2000. The peripheral myelin protein 22 and epithelial membrane protein family. Prog Nucl Acid Res Mol Biol 64: 97-129.

Jovov B, Van Itallie CM, Shaheen NJ, Carson JL, Gambling TM, Anderson JM, Orlando RC. 2007. Claudin-18: A Dominant Tight Junctional Protein in Barrett's Esophagus and Potential Contributor to its Acid Resistance. Am J Physiol GI 293: G1106-G1113.

Kausalya PJ, Amasheh S, Gunzel D, Wurps H, Muller D, Fromm M, Hunziker W. 2006. Disease-associated mutations affect intracellular traffic and paracellular
$\mathrm{Mg}$ transport function of Claudin-16. J Clin Invest 116: 878-891.

Kaushansky N, Hemo R, Eisenstein M, Ben Nun A. 2007. OSP/claudin-11-induced EAE in mice is mediated by pathogenic $\mathrm{T}$ cells primarily governed by OSP192Y residue of major encephalitogenic region OSP179-207. Eur J Immunol 37: 2018-2031.

Kearsey J, Petit S, De Oliveira C, Schweighoffer F. 2004. A novel four transmembrane spanning protein, CLP24. Eur J Biochem 271: 2584-2592.

Knipp GT, Ho NF, Barsuhn CL, Borchardt RT. 1997. Paracellular diffusion in Caco-2 cell monolayers: Effect of perturbation on the transport of hydrophilic compounds that vary in charge and size. J Pharm Sci 86: 1105-1110.

Koefeld-Johnsen V, Ussing HH. 1958. The nature of the frog skin potential. Acta Physiol Scand 42: 298-308.

Konrad M, Schaller A, Seelow E, Pandey AV, Waldegger S, Lesslauer A, Vitzthum H, Suzuki Y, Luk JM, Becker C, et al. 2006. Mutations in the tight-junction gene claudin 19 (CLDN19) are associated with renal magnesium wasting, renal failure, and severe ocular involvement. Am J Hum Genet 79: 949-957.

Krause G, Winkler L, Mueller SL, Haseloff F, Piontek J, Blasig IE. 2008. Structure and function of claudins. Biochim Biophys Acta 1778: 631-645.

Kubota K, Furuse M, Sasaki H, Sonoda N, Fujita K, Nagafuchi A, Tsukita S. 1999. $\mathrm{Ca}^{2+}$-independent cell-adhesion activity of claudins, a family of integral membrane proteins localized at tight junctions. Curr Biol 9: 1035-1038.

Ladwein M, Pape UF, Schmidt DS, Schnolzer M, Fiedler S, Langbein L, Franke WW, Moldenhauer G, Zoller M. 2005. The cell-cell adhesion molecule EpCAM interacts directly with the tight junction protein claudin-7. Exp Cell Res 309: 345-357.

Laukoetter MG, Nava P, Lee WY, Severson EA, Capaldo CT, Babbin BA, Williams IR, Koval M, Peatman E, Campbell JA, et al. 2007. JAM-A regulates permeability and inflammation in the intestine in vivo. J Exp Med 204: 3067-3076.

Le Naour F, Zoller M. 2008. The tumor antigen EpCAM: Tetraspanins and the tight junction protein claudin-7, new partners, new functions. Front Biosci 13: 5847-5865.

Liu Y, Nusrat A, Schnell FJ, Reaves TA, Walsh S, Pochet M, Parkos CA. 2000. Human junction adhesion molecule regulates tight junction resealing in epithelia 18. J Cell Sci 113: 2363-2374.

Ma TY, Boivin MA, Ye D, Pedram A, Said HM. 2005. Mechanism of TNF-\{alpha\} modulation of Caco-2 intestinal epithelial tight junction barrier: Role of myosin light-chain kinase protein expression. Am J Physiol Gastrointest Liver Physiol 288: G422-G430.

Madara JL, Trier JS, Neutra MR. 1980. StructuralChanges in the Plasma-Membrane Accompanying Differentiation of Epithelial-Cells in Human and Monkey Small-Intestine. Gastroenterology 78: 963-975.

Matsuda M, Kubo A, Furuse M, Tsukita S. 2004. A peculiar internalization of claudins, tight junction-specific adhesion molecules, during the intercellular movement of epithelial cells. J Cell Sci 117: 1247-1257. 
McCarthy KM, Francis SA, McCormack JM, Lai J, Rogers RA, Skare IB, Lynch RD, Schneeberger EE. 2000. Inducible expression of claudin-1-myc but not occludin-VSV-G results in aberrant tight junction strand formation in MDCK cells. J Cell Sci 113: 3387-3398.

Mitic LL, Unger VM, Anderson JM. 2003. Expression, solubilization, and biochemical characterization of the tight junction transmembrane protein claudin-4. Protein Sci 12: $218-227$.

Nitta T, Hata M, Gotoh S, Seo Y, Sasaki H, Hashimoto N, Furuse M, Tsukita S. 2003. Size-selective loosening of the blood-brain barrier in claudin-5-deficient mice. J Cell Biol 161: 653-660.

Notterpek L, Roux KJ, Amici SA, Yazdanpour A, Rahner C, Fletcher BS. 2001. Peripheral myelin protein 22 is a constituent of intercellular junctions in epithelia. Proc Natl Acad Sci 98: 14404-14409.

Nusrat A, Turner JR, Madara JL. 2000. Molecular physiology and pathophysiology of tight junctions. IV. Regulation of tight junctions by extracellular stimuli: Nutrients, cytokines, and immune cells. Am J Physiol Gastrointest Liver Physiol 279: G851-G857.

Nusrat A, Eichel-Streiber C, Turner JR, Verkade P, Madara JL, Parkos CA. 2001. Clostridium difficile toxins disrupt epithelial barrier function by altering membrane microdomain localization of tight junction proteins. Infect Immun 69: 1329-1336.

Piontek J, Winkler L, Wolburg H, Muller SL, Zuleger N, Piehl C, Wiesner B, Krause G, Blasig IE. 2007. Formation of tight junction: Determinants of homophilic interaction between classic claudins. FASEB J 22: $146-158$.

Powell DW. 1981. Barrier function of epithelia. Am J Physiol 241: G275-G288.

Price MG, Davis CF, Deng F, Burgess DL. 2005. The alpha-amino-3-hydroxyl-5-methyl-4-isoxazolepropionate receptor trafficking regulator "stargazin" is related to the claudin family of proteins by Its ability to mediate cell-cell adhesion. J Biol Chem 280: 19711-19720.

Riazuddin S, Ahmed ZA, Fanning AS, Lagziel A, Kitajiri S, Ramzan K, Khan SN, Chattaraj P, Friedman PL, Anderson JM, et al. 2006. Tricellulin is a tight-junction protein necessary for hearing. Am J Hum Genet 79: $1040-1051$.

Roh MH, Liu CJ, Laurinec S, Margolis B. 2002. The carboxyl terminus of zona occludens- 3 binds and recruits a mammalian homologue of discs lost to tight junctions. J Biol Chem 277: 27501-27509.

Roux KJ, Amici SA, Notterpek L. 2004. The temporospatial expression of peripheral myelin protein 22 at the developing blood-nerve and blood-brain barriers. J Comp Neurol 474: $578-588$.

Roux KJ, Amici SA, Fletcher BS, Notterpek L. 2005. Modulation of epithelial morphology, monolayer permeability, and cell migration by growth arrest specific 3/peripheral myelin protein 22. Mol Biol Cell 16: 1142-1151.

Saitou M, Furuse M, Sasaki H, Schulzke JD, Fromm M, Takano H, Noda T, Tsukita S. 2000. Complex phenotype of mice lacking occludin, a component of tight junction strands. Mol Biol Cell 11: 4131-4142.
Physiology and Function of the Tight Junction

Schmitz H, Barmeyer C, Fromm M, Runkel N, Foss HD, Bentzel CJ, Riecken EO, Schulzke JD. 1999. Altered tight junction structure contributes to the impaired epithelial barrier function in ulcerative colitis. Gastroenterology 116: 301-309.

Schneeberger EE, Lynch RD. 2004. The tight junction: A multifunctional complex. Am J Physiol-Cell Physiol 286: C1213-C1228.

Schulzke JD, Gitter AH, Mankertz J, Spiegel S, Seidler U, Amasheh S, Saitou M, Tsukita S, Fromm M. 2005. Epithelial transport and barrier function in occludindeficient mice. Biochim Biophys Acta 1669: 34-42.

Simon DB, Lu Y, Choate KA, Velazquez H, Al Sabban E, Praga M, Casari C, Bettinelli C, Colussi C, Rodriguez-Soriano J, et al. 1999. Paracellin-1, a renal tight junction protein required for paracellular $\mathrm{Mg}^{2+}$ resorption. Science 285: 103-106.

Steele EC, Lyon MF, Favor J, Guillot PV, Boyd Y, Church RL. 1998. A mutation in the connexin 50 (Cx50) gene is a candidate for the No2 mouse cataract. Curr Eye Res 17: 883-889.

Tamura A, Kitano Y, Hata M, Katsuno T, Moriwaki K, Sasaki H, Hayashi H, Suzuki Y, Noda T, Furuse M, et al. 2008. Megaintestine in claudin-15-deficient mice. Gastroenterology 134: 523-534.

Tiwari-Woodruff SK, Buznikov AG, Vu TQ, Micevych PE, Chen K, Kornblum HI, Bronstein JM. 2001. OSP/ claudin-11 forms a complex with a novel member of the tetraspanin super family and beta 1 integrin and regulates proliferation and migration of oligodendrocytes. J Cell Biol 153: 295-305.

Tomita S, Fukata M, Nicoll RA, Bredt DS. 2004. Dynamic interaction of stargazin-like TARPs with cycling AMPA receptors at synapses. Science 303: 1508-1511.

Tsukita S, Yamazaki Y, Katsuno T, Tamura A, Tsukita S. 2008. Tight junction-based epithelial microenvironment and cell proliferation. Oncogene 27: 6930-6938.

Turner JR. 2006. Molecular basis of epithelial barrier regulation: From basic mechanisms to clinical application. Am J Pathol 169: 1901-1909.

Ussing HH, Windhager EE. 1964. Nature of shunt path and active sodium transport path through frog skin epithelium. Acta Physiol Scand 61: 484-504.

Ussing HH, Zerahn K. 1951. Active transport of sodium as the source of electric current in the shortcircuited isolated frog skin. Acta Physiol Scand 23: $110-127$.

Van Itallie CM, Fanning AS, Anderson JM. 2003. Reversal of charge selectivity in cation or anion-selective epithelial lines by expression of different claudins. Am J Physiol Renal Physiol 285: F1078-F1084.

Van Itallie C, Rahner C, Anderson JM. 2001. Regulated expression of claudin- 4 decreases paracellular conductance through a selective decrease in sodium permeability. J Clin Invest 107: 1319-1327.

Van Itallie CM, Anderson JM. 2004. The Role of Claudins in Determining Paracellular Charge Selectivity. Proc Am Thorac Soc 1: 38-41.

Van Itallie CM, Anderson JM. 2006. Claudins and Epithelial Paracellular Transport. Annu Rev Physiol 68: 403-429. 
J.M. Anderson and C.M. Van Itallie

Van Itallie CM, Rogan S, Yu A, Vidal LS, Holmes JL, Anderson JM. 2006. Two splice variants of claudin-10 in the kidney create paracellular pores with different ion selectivities 1. Am J Physiol Renal Physiol 291: F1288-F1299.

Van Itallie CM, Holmes J, Bridges A, Gookin JL, Coccaro MR, Proctor W, Colegio OR, Anderson JM. 2008. The density of small tight junction pores varies among cell types and is increased by expression of claudin- 2 . J Cell Sci 121: 298-305.

Vetrano S, Rescigno M, Cera MR, Correale C, Rumio C, Doni A, Fantini M, Sturm A, Borroni E, Repici A, et al. 2008. Unique role of junctional adhesion molecule-a in maintaining mucosal homeostasis in inflammatory bowel disease. Gastroenterology 135: 173-184.

Wang Z, Mandell KJ, Parkos CA, Mrsny RJ, Nusrat A. 2005. The second loop of occludin is required for suppression of Raf1-induced tumor growth. Oncogene 24: 4412-4420.

Watson CJ, Rowland M, Warhurst G. 2001. Functional modeling of tight junctions in intestinal cell monolayers using polyethylene glycol oligomers. Am J Physiol-Cell Physiol 281: C388-C397.

Watson CJ, Hoare CJ, Garrod DR, Carlson GL, Warhurst G 2005. Interferon-gamma selectively increases epithelial permeability to large molecules by activating different populations of paracellular pores. J Cell Sci 118: 5221-5230.

Wen HJ, Watry DD, Marcondes MCG, Fox HS. 2004. Selective decrease in paracellular conductance of tight junctions: Role of the first extracellular domain of claudin-5. Mol Cell Biol 24: 8408-8417.
Wright EM, Diamond JM. 1968. Effects of $\mathrm{pH}$ and polyvalent cations on the selective permeability of gallbladder epithelium to monovalent ions. Biochim Biophys Acta 163: 57-74.

Wu VM, Schulte J, Hirschi A, Tepass U, Beitel GJ. 2004. Sinuous is a Drosophila claudin required for septate junction organization and epithelial tube size control. J Cell Biol 164: 313-323.

Yamazaki Y, Okawa K, Yano T, Tsukita S, Tsukita S. 2008. Optimized proteomic analysis on gels of cell-cell adhering junctional membrane proteins. Biochem 47: $5378-5386$.

Yeaman C, Grindstaff KK, Nelson WJ. 2004. Mechanism of recruiting Sec6/8 (exocyst) complex to the apical junctional complex during polarization of epithelia cells. J Cell Sci 117: 559-570.

Yu AS, Enck AH, Lencer WI, Schneeberger EE. 2003. Claudin-8 expression in Madin-Darby canine kidney cells augments the paracellular barrier to cation permeation. J Biol Chem 278: 17350-17359.

Yu AS, McCarthy KM, Francis SA, McCormack JM, Lai J, Rogers RA, Lynch RD, Schneeberger EE. 2005. Knock down of occludin expression leads to diverse phenotypic alterations in epithelial cells. Am J Physiol Cell Physiol 288: C1231-C1241.

Yu AS, Cheng MH, Angelow S, Gunzel D, Kanzawa SA, Schneeberger EE, Fromm M, Coalson RD. 2009. Molecular Basis for Cation Selectivity in Claudin-2-based Paracellular Pores: Identification of an Electrostatic Interaction Site. J Gen Physiol 133: 111-127. 


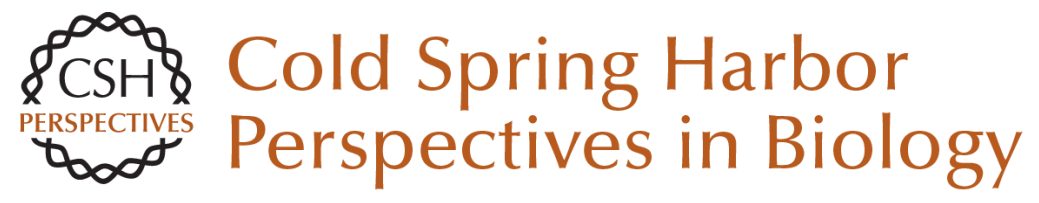

\section{Physiology and Function of the Tight Junction}

James M. Anderson and Christina M. Van Itallie

Cold Spring Harb Perspect Biol 2009; doi: 10.1101/cshperspect.a002584

Subject Collection Cell-Cell Junctions

Vascular Endothelial (VE)-Cadherin, Endothelial

Adherens Junctions, and Vascular Disease

Maria Grazia Lampugnani, Elisabetta Dejana and

Costanza Giampietro

Adherens Junctions and Desmosomes

Coordinate Mechanics and Signaling to

Orchestrate Tissue Morphogenesis and Function:

An Evolutionary Perspective Matthias Rübsam, Joshua A. Broussard, Sara A. Wickström, et al.

Cell-Cell Contact and Receptor Tyrosine Kinase

Signaling

Christine Chiasson-MacKenzie and Andrea I. McClatchey

Hold Me, but Not Too Tight--Endothelial Cell-Cell Junctions in Angiogenesis Anna Szymborska and Holger Gerhardt

Connexins and Disease Mario Delmar, Dale W. Laird, Christian C. Naus, et al.

Cell Junctions in Hippo Signaling Ruchan Karaman and Georg Halder

Loss of E-Cadherin-Dependent Cell-Cell Adhesion and the Development and Progression of Cancer Heather C. Bruner and Patrick W.B. Derksen
Signaling by Small GTPases at Cell-Cell Junctions: Protein Interactions Building Control and Networks

Vania Braga

Making Connections: Guidance Cues and Receptors at Nonneural Cell-Cell Junctions lan V. Beamish, Lindsay Hinck and Timothy E. Kennedy

The Cadherin Superfamily in Neural Circuit Assembly James $D$. Jontes

Mechanosensing and Mechanotransduction at Cell-Cell Junctions Alpha S. Yap, Kinga Duszyc and Virgile Viasnoff

Beyond Cell-Cell Adhesion: Sensational Cadherins for Hearing and Balance Avinash Jaiganesh, Yoshie Narui, Raul Araya-Secchi, et al.

Cell-Cell Junctions Organize Structural and Signaling Networks Miguel A. Garcia, W. James Nelson and Natalie Chavez

Cell Biology of Tight Junction Barrier Regulation and Mucosal Disease Aaron Buckley and Jerrold R. Turner

For additional articles in this collection, see http://cshperspectives.cshlp.org/cgi/collection/

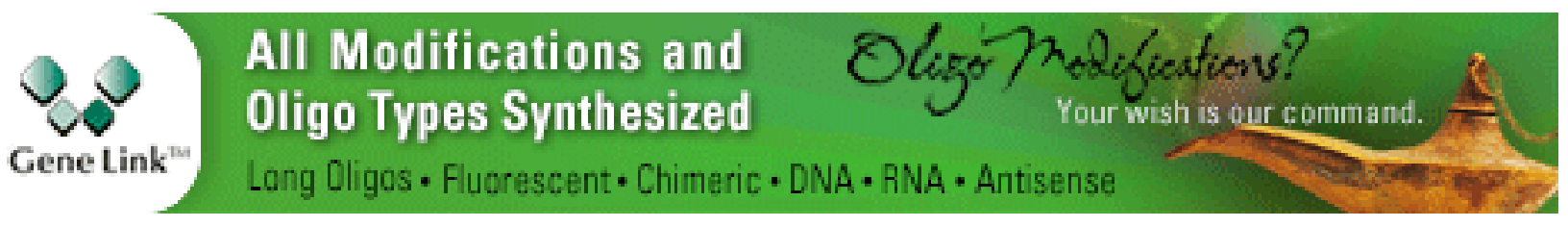


Desmosomes and Intermediate Filaments: Their Consequences for Tissue Mechanics Mechthild Hatzfeld, René Keil and Thomas M. Magin
Integration of Cadherin Adhesion and

Cytoskeleton at Adherens Junctions

René Marc Mège and Noboru Ishiyama

For additional articles in this collection, see http://cshperspectives.cshlp.org/cgi/collection/

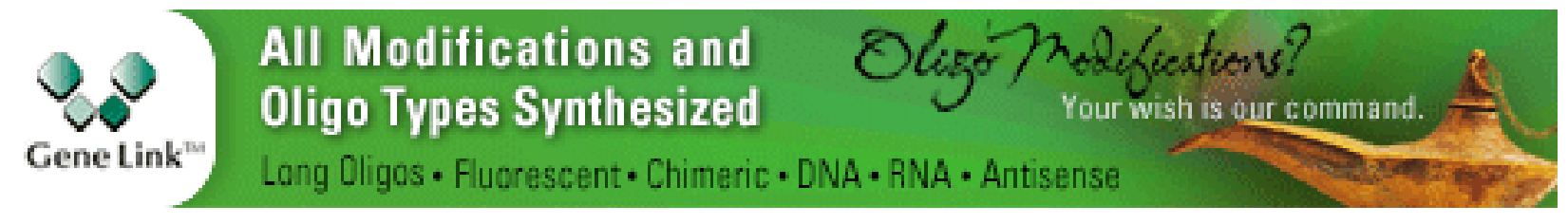

Copyright @ 2009 Cold Spring Harbor Laboratory Press; all rights reserved 